\title{
Challenges and Prospects of Private Broadcast Media Ownership in Nigeria: A Study of Stations in Port Harcourt
}

\section{Chieme Azubuike}

Department of Mass Communication, Captain Elechi Amadi Polytechnic, Rumuola, Port Harcourt, Rivers State

Stella I.G. Ikiriko

Department of Mass Communication, Captain Elechi Amadi Polytechnic, Rumuola, Port Harcourt, Rivers State

Doi: $10.2478 / \mathrm{mjss}-2019-0070$

\section{Abstract}

Ownership of the media was vested with the government, especially in the areas of issuance of licenses and renewal of such licenses, among others, through the National Broadcasting Commission empowered to carry out such salient responsibility. The empowerment of NBC through the enabling Decree in 1992 saw the emergence of private broadcast stations in Nigeria. But years after the deregulation of the broadcast media in Nigeria, the private broadcast stations and ownership are still bedeviled with some challenges, which If not well addressed, will leave them at cross roads; but if addressed properly, the sky would be too small to be their limit. To realize these, the study examined the challenges and prospects of private broadcast media using Africa Independent Television (AIT) and Rhythm 93.7fm as case studies. The survey method was used to expose the challenges faced by these stations and their prospects. In course of the study, the following findings, interalia, were discovered: that the private broadcast outfits are faced with challenges arising from poor facilities, government regulation and legislations, expensive equipment, welfare and debts. However, the study discovered that progress could be made if enabling environment would be created for them to strive.

Keywords: Challenges, Prospects, Private, Broadcast, Media, Ownership

\section{Background of Study}

Broadcasting and the electronic media are the vehicle through which diverse audiences get abreast with the happenings in the society, especially in this era of globalization. Akpan, $(2002$, p.3) made this fact more explicit when he described broadcasting as the systematic dissemination of entertainment, information, educational and other features for simultaneous reception by a scattered audience individually or in group Electronic media are known for their immediacy of impact, their potentially wider reach, and their ability to transcend the banners of literacy and education to a particularly diverse audience. Thus, Abubakar (1993, p.183) succinctly notes that, "the electronic media refer only to radio and televisions. These forms of mass media reach millions of people simultaneously and with immediacy..." Moreover, the electronic media have also emerged as the most powerful tools for influencing the direction of public opinion in any modern society (Izuora 1993, p.190).

Ezeokoli, (1993, p.201) reaffirms that television (broadcasting) is by far the most potent 
medium, because of the immediacy and intimacy of it transmission. It is also, therefore, why Odetoyinbo (2001, p.2) posits that broadcasting has been found to be a force to be reckoned with in the development of nations all over the world. It presupposes that broadcasting is a bridge building tool for development.

It suffices to say that to realize these tasks, there must be ownership of media. Media ownership was hitherto left in the hands of governments, state and federal. In 1977, the Federal Military Government took over all television broadcasting stations in Nigeria and placed them under the authority of the Nigeria Television Authority (NTA). Powerful short wave radio stations were also taken over and placed under the Federal Radio Corporation of Nigeria (FRCN). This gave strong influence on government as the sole transmitter of signals to diverse audiences in the country. During this period, the government dictated what went on air and how.

There was however a turn of events in 1992 as broadcasting was deregulated via promulgation of Decree 38 by the then military government headed by General Ibrahim Babaginda. It was called Decree 38, 24 August, 1992 of the Federal Military Government, Gazette extraordinary No.33:1992. This gave birth to the broadcasting commission which was empowered to act as a guide to broadcast outfits. Nwanze (2003, p.9) said they were to, among other things, advise the Federal Military Government generally on the implementation of the National Mass Communication Policy, with particular reference to broadcasting; regulating and controlling the broadcast industry.

This scenario gave rise to the recognition of private broadcast media establishments in the country, a situation which liberalized and deregulated the process of broadcasting in Nigeria. It happened people to have more access to information and information dissemination process in Nigeria. The process of information dissemination was no longer seen as exclusive for the government media and their owners, rather required the contributions of the private broadcast outfits to move the sector forward, hence Daar Communications Limited applied for licence for television in Nigeria, and Daar Communications Limited received licence for direct Satellite television in June, 1995. It then started operating the Satellite television with call sign - AIT (Africa Independent Television) to local and global audience (Nwanze 2003, p.15).

It is also in line with the foregoing that Silverbird Group got the leverage which empowered her to seek for broadcast licence. In January, 2004, Silverbird Group commenced commercial transmission of Silverbird Television, a family entertainment channel. The station has very high quality programmes and clear reception which is the reason for very wide viewership in Nigeria. This becomes the foundation on which the establishment of the Rhythm $93.7 \mathrm{fm}$ was based. Above all, the contributions of the private broadcast media to the enlightenment, information and education of the general populace cannot be overstressed. However, these contributions are not devoid of challenges. It is, therefore, the main thrust of this expository study, which is geared towards digging out the prospects inherent in this sector and proffering solutions to the detected challenges.

\subsection{Statement of Problem}

The public media exist in Nigeria, like their private counterparts with problems starring them on their faces. Even though, the government media outfits exist under the cover and protection of the government, they still are not free from problems which impede their growth and development. No doubt, the government owned media outfits are bedeviled with such problems as the continuous use of out-dated equipment, thereby failing to catch up with the changes of globalization which are known for modernity: the non-availability of training and retraining opportunities, which is the bedrock for enhanced productivity; poor remuneration for staff, thereby having low motivation to perform optimally and above all, the teleguidance of management and staff by their employers Government, hence only projecting the activities of government with little or no regard for their responsibility to the public.

This situation is not different with the private broadcast media. Obviously, the private media are incessantly and continuously bedeviled with myriad of challenges, such that they are almost always forced to leave the business of discharging their social responsibility to the disadvantage of the citizenry. First, there seems to be the problem of interference from government and its agencies. It is because of this that Nwanze (2003, p.9) stressed that "National Security, peace and 
stability are better enhanced through a free media with inbuilt regulatory machinery that are inherently oppressive and suppressive". Similarly, the government through management seems to employ the use of censorship to gag and cage the press. In the process, government is believed to attempts to not only control but subjugate the press through obnoxious laws have remained an enduring problem.

Moreover, the private outfits are also believed to be confronted with the problem of lack or paucity of fund, especially to acquire the needed equipment which are quite expensive. Though training is somewhat pursued by the private broadcast media, the best is yet to be seen from them. There are no welfare opportunities for the staff of the private broadcast outfits, as their salaries for some are still considered as nothing to write home about. In fact, some are reported to owe backlogs of salaries. The regulatory bodies also are accused of using of the process of issuance of licence to ventilate anger on private broadcast outfits, especially when owners do not belong to the same political outfits especially cartels with those in power.

These seeming problems, invariably, are likely to truncate information dissemination, thereby leading to starving the populace of the information they require and putting question marks on the media social responsibility functions. Thus, the need arises for proper evaluation and assessment of these problems and exploration of the prospects of the private media amidst perceived challenges. It is, therefore, against this backdrop that this study is focused or derives its aim with emphasis on Africa Independent Television (AIT) and Silverbird's Rhythm 93.7fm in Port Harcourt.

\subsection{Objectives of Study}

The goals of this research are:

i. To identify the challenges faced by private media in Nigeria;

ii. To determine the challenges peculiar to AIT and Rhythm $93.7 \mathrm{fm}$ as private broadcast stations;

iii. To ascertain the prospects of private broadcast media in Nigeria.

\subsection{Research Questions}

Based on the above mentioned objectives, this study will be guided by the following research questions:

i. What are the challenges faced by private broadcast media in Nigeria?

ii. Are there challenges peculiar to AIT and Rhythm $93.7 \mathrm{fm}$ as private broadcast stations?

iii. What are the prospects of private broadcast media in Nigeria?

\subsection{Theoretical Framework}

\subsubsection{Social Responsibility Theory}

The Social Responsibility Theory is hinged on responding to the yearnings and aspirations of the populace by socially responding to their needs. Against this background, the media are presumed to have duties to perform, and according to (Okon 1996 and Mcquail 1987) these duties include:

i. The press should provide an avenue for exchange of comment and criticism.

ii. They should provide a representative picture of all elements of the society.

iii. They should be responsible for the identification and presentation of goals and values of the society.

iv. Provide full access in today's intelligence.

v. Provide a comprehensive account in a context that gives them meaning.

The press, thus, have so much to offer to the citizenry. The citizens must be confident in having the press on their side, no matter the threat; they must be consistent in delivering to the public the goals of this profession. In view of this, Okoro and Agbo (2003, p.23) say: "The major opinion being canvassed by the social responsibility theorists is that the media should fulfill certain obligations and expectation for the society. It is in doing so that the media become socially 
responsible".

It is on the strength of this that, in 1947, Hutchins Commission came out in the United States of America to promote freedom of press and fulcrum on which media got a support to operate. It articulated the theory of social responsibility which empowers the media to operate putting at the back of their mind the fact that the citizenry must be informed of the goings-on in the society where they live. According to Asemah, Nwammuo and Nkwam-Umaoma (2017, p.48) the commission emerged "as a result of the negative activities by the press due to press freedom, the Hutchin Commission was set up in 1947 to look into criticism of the press." To them, "...freedom and responsibility go hand in hand and that the press should be periodically reminded of its responsibility"

Therefore, ownership of media dovetails with the responsibility of disseminating information to the populace. However, to realize or actualize this lofty responsibility, the media should be afforded the opportunity to do so, by creating an enabling environment devoid of gagging and unconstructive checks on them, which will only leave them falling short of discharging this social responsibility, hence the adequacy and aptness of this theory and the need for its application for this particular study.

\section{Literature Review}

\subsection{The Emergence of National Broadcasting Commission}

In 1992, with the promulgation of Decree 38 by the military Administration of General Ibrahim Babaginda consequently opened windows of opportunity for many entrepreneurs to invest in the broadcast media industry. To further show the commitment attached to this decree, another Military Administration of General Abdulsalami Abubakar amended the Decree, as the National Broadcasting Commission (Amendment) Decree No. 55 of 1999. The Decree, therefore, did away with the state monopoly of broadcasting by providing for licensing of private individuals to establish, own or operate radio and television stations, which for more than 50 years had been the sole authority of various states and federal governments. Interestingly, the decree created an opportunity for foreign investors to participate in the establishment of stations, a situation which never happened in the past.

The National Broadcasting Commission (NBC) from 1992 till date has been in the centre stage of increasing the number of broadcast stations and broadcast development in Nigeria. Thus, National Broadcasting Commission is the administrative agent of the Federal Government of Nigeria on general broadcast policies. Government relies on the Commission for expert judgment on regulatory problems and formulation of general broadcast policies (Nwanze, 2003, p.94).

\subsection{Media Ownership Patterns in Nigeria}

Ownership of media currently revolves around the forms or patterns of ownership. According to Okoro (2003, p.35), media ownership in Nigeria, has three categories which he explained this way:

i. Government ownership

ii. Private ownership

iii. Mixed ownership

To this end, Okoro established that the Government ownership is a situation where the medium is completely financed by the government. For example, Nigeria Television Authority (NTA); Federal Radio Corporation of Nigeria (FRCN) as well as broadcast outfits owned by State Government.

To him, Private ownership refer to the situation where individuals (one person or group of persons) establish, finance and direct the administration of the media organization, for instance, MINAJ, AIT, SILVERBIRD. In this regard, the individual or individuals see to the success of the station in all ramifications.

There is also what Okoro (2003) referred to as Mixed ownership, which is explained as, a situation where the government and private individuals participate in financing the medium. One or 
two examples may help here. For example, in 2008, the Rivers State Government during the regime of Rt. Hon. Rotimi Amaechi partnered with the Silverbird Group, operators of Silverbird Television, Silverbird Cinema and Rhythm $93.7 \mathrm{fm}$ to establish a cinema and media centre for the interest of citizenry by providing a parcel of land, while the group embarked on the building and commencement of the cinema house. This was achieved through the instrumentality of Private Public Partnership (PPP) arrangement.

\subsection{Private Media and their Operations}

Broadcasting got a major boost through the liberation of the sector via deregulation. It is this deregulation that became the foundation on which the private media houses grew. Private broadcasting as the name implies, means the establishment of either television or radio station or both by an individual or group of individuals. It means that this individual and his partners bear the responsibility of running the day-to-day activities of the station.

It is important to note that private television stations are required by the enabling deregulatory decree to broadcast programmes in accordance with the stipulated ratio of 60:40 percent for locally produced and imported programmes. The management and staff of the private media stations must also have self-regulatory measures to prevent incessant interferences from the regulatory body. In doing this, there must be internal control measures spelt out by the management of the organization. Abati in the Guardian, Wednesday, July 21, 2004 lays bare this assertion thus: "Internal control system in an organization is the system put in place to ensure that tasks are carried out in an orderly manner. Thus, in doing this, the paper described that the worker "in execution of daily activities, employers put in place checks and balances to curb excesses of employees, to avoid derailment from policies of the organization. Internal control system seeks to harmonize the interest of various stakeholders to achieve common objective".

It is expedient to assert that broadcasting operate with laid down objectives. These objectives are also the main focus of private media organizations. It is on the strength of this that, Akpan (2002, p.2) establishes the following objectives of broadcast media as to inform, "to educate and to entertain".

Private broadcast organizations have their operations segmented for effectiveness. In doing this, the organization is departmentalized proven to be capable of handling the activities of the department. The major departments in a private broadcast station include: Administrative Department, Engineering, News, Programmes, Production, Security, Marketing/Sales, Accounts.

It is instructive to note that within these departments or units, there are sub units. These units or subunits work hand-in-hand. No department or sub-department is an island. In broadcasting (private) success is dependent on the inputs of all the departments. For example, News cannot be aired if the production department does not edit the news. It is a common knowledge, therefore, to state that broadcast in all ramifications is about team work, as no one works in isolation.

\subsection{Challenges and Prospects}

Private broadcast ownership in Nigeria is not devoid of challenges. Obviously, a challenge in virtually every endeavour is a must-happen. So, it is not out of place, sometimes, to experience challenges or setbacks, but what is important is how they are handled. There are lots of challenges facing private media owners in Nigeria. They come in numerous dimensions. Some of these dimensions are what Umechukwu (2001) puts thus:

With regard to the law, it must be accepted that the media house, private or otherwise function under strict government regulations, they are not free to air every news items as they arrive. For the private media, they must contend with law enabling their establishment... (p.118)

Categorically, one major challenge was highlighted by Iruene, $(2003, p .15)$ to what he referred to as technology backwardness. He puts it thus: "Technology backwardness of African countries such as Nigeria cost a big challenge to the Nigeria media..." Umechukwu (2001, p.118) opines that 
funding is a big challenge. He puts it this way: "Other problems range from poor funding. On poor funding, it has been observed that operation of mass media is capital intensive."

In the same vein, Sanusi, et al, in Sunday Times, August 24, 1997, made the fact clearer when they established interalia, the problems associated with private media ownership in Nigeria this way; "...some of these problems could be traced to non-standardization of equipment in the industry such that there is equipment incompatibility, lack of local technological input into broadcasting and lopsided coverage of the country. These coupled with low, economic programme sponsorship almost mar smooth operation..." Another problem of private media organization is the issuance of licenses. No doubt, this is the nucleus of the problem bedeviling private media owners, as some government officials use it to show the aura of hegemony. The issue of licence is used to battle opponents who venture into the business of broadcasting.

Another area of interest is the use of media by rival political interest groups to discredit political enemies. As a matter of fact, this forms a pattern of control prevalent in the broadcasting sector. It is in explaining this that Akpan $(2002$, p.10) establishes that: "Rival political parties set up radio television stations to discredit political enemies". What Akpan is stressing here is that owners of media outfits, especially politicians dictate what happens in their outfits thereby not allowing a level playing ground for professionals' potentials, as they are usually directed on what and how to perform their duties.

Censorship is another major challenge facing the private broadcast media. It is a 'cog in the wheel' of progress of media houses, as a whole and the private ones are no exceptions Yalaju, (2001, p.27) said this of censorship, while quoting George Bernard Shaw, "censorship is extreme form of assassination of truth." According to Okoro, (2003, p. 46) censorship comes in many forms, but the worst of them is what he describes thus: "They clampdown on media (private) houses, arresting journalists, carting away publication and sometimes proscribing the media houses".

Recently, the National Broadcasting Commission (NBC) announced as direceted the revocation of the operating licence of Daar Communications Plc, operators of Africa Independent Television (AIT), Raypower and Faagi fm radio stations for unprofessional conduct, promotion of hate speech and inability to renew the operational licence. This move was challenged in a competent court of law citing the failure of NBC to follow due process in issuance of the revocation order as well as inhibiting the known principle of fair hearing. Hoever, the court granted the parties the leave to settle out of court and, consequently, Daar Communications licence has been restored following the resolution of the imbroglio by the parties.

Aside from the foregoing, another crucial challenge facing private broadcast media is ethnicity, especially in a country like Nigeria, where diversity is just natural. The private media owners tend to protect the ethnic group of their own. Udoakah (1998) points out thus: "... instead of the information media in capitalistic societies to lift men up and educate them, they tend to labour their sights and keep them at the level of docile consumers." In the same vein, he explains that: "... Media of mass information now shut out issues that are fundamental to the harmonious co-existence of the various ethnic groups and trade on sensational hews stories and official explanations that often raise more questions than they answer."

Worthy of note also is the case of worker's welfare. It is on the strength of this that, the Guardian Monday, June 28, 2004 wrote: "Salaries are not paid regularly and indispensable empowerment programmes are recklessly abandoned." This situation has been responsible for the incessant failure of journalists to adhere to the ethics of the profession as they have to "keep body and soul together' by looking inwards to survey, thereby destroying the dignity of the profession and reducing the productivity level of the workers with inherent disadvantages.

Another major challenge of private media outfits is programming. It is a common knowledge that programming is the life-wire of any broadcast outfits, and so, in the event of non-creation of programmes, the station is left to the fate of dependence on other sources of programmes, especially on foreign programmes. It is this dependence that has bedeviled the private broadcast outfits a great deal.

Obviously, a myriad of problems have confronted broadcasting services in Nigeria, especially the television services. 


\subsection{Prospects}

Despite the challenges bedeviling the private broadcast media and owners, there is still a 'silver lining across the dark sky.' No wonder, Umechukwu (2001, p.120) observes: 'With the present democratic dispensation in Nigeria, the private media houses have bright future with the positive wind of change blowing, they stand to benefit from the following effects and innovations which have been ushered in by the nascent fourth democratic experiment: human right protection, press freedom, privatization of the government mass media, constitutional review, growth in information technology, globalization, economic improvement and reformation."

Interestingly, if a forum for healthy competition is created between the public and private owned media organizations, there would be room for improvement of broadcasting generally, both for private and public outfits.

Above all, if tenets of Journalism are adhered to, as well as responding to the welfare of staff and procuring relevant equipment, training of staff, and other concomitant measures are followed, then, broadcasting, especially private outfits would be a haven for investors and practitioners, hence, Nwanze (2003, p.20) concludes: "Private operators of broadcast media should ensure that they comply with all the provisions of the relevant laws and legislation governing the industry. By so doing, the chequered history of government press relations in Nigeria would be re-enacted in the private electronic media, broadcast stations should not allow themselves to be used to destabilize the nation. Harmful prejudice, stereotypes and sentiments must be avoided and expunged from broadcast materials. They should adopt and maintain objectivity and distance themselves from partisan politics. Their immense potentials for the enhancement and development of society should be maximized to the full.

In essence, the job must be done with the tenets of the profession put into consideration and, a mark would be left for posterity to take pre-eminence.

\section{Methodology}

The survey research design was adopted for this study as it studies both large and small populations. The population of this study comprises of all the 'private independent media stations in Nigeria. However, because of the total size of the entire population and the complexities involved in studying the large sizes, the researchers selected staff of two private broadcast stations, Africa Independent Television (AIT), and Silverbird's Rhythm. 93.7fm. To further work with a considerable population which will ensure reliability, the study worked with three hundred and sixty four members of the two stations. Two hundred (one hundred from each station) from the total population were purposively selected as the sample size of the study. This number was derived from all departments, and classes of staff.

\section{Data Presentation and Analysis}

In analyzing the data gathered, response were converted into raw scores and then to percentages. The data were tabulated, summarized and adequately explained. The Australian sample size calculator was used to determine the sample size for the study which is put at one hundred and eighty seven.

$\begin{array}{rlr}\text { Confidence Level } & =95 \% \\ \text { Population Size } & =364 \\ \text { Confidence Interval } & =0.04998 \\ \quad \text { Upper } & =0.54998 \\ \text { Lower } & =0.45002 \\ \text { Standard Error } & =0.02550 \\ \text { Relative Standard Error } & =5.1 \\ \text { Sample Size } & =187\end{array}$

Thus, one hundred and eighty seven questionnaire was distributed to the two stations out of which one hundred and sixty three set of the questionnaire were retrieved of which eighty five came 
from Africa Independent Television (AIT), while seventy eight was from Rhythm $93.7 \mathrm{fm}$; bringing the total number to one Hundred and sixty three.

\subsection{Research Question One: What are the challenges faced by private broadcast media in Nigeria?}

Table 1: Challenges affecting private broadcast media

\begin{tabular}{|l|c|c|c|c|c|c|c|c|c|c|c|c|c|c|c|}
\hline Station & \multicolumn{2}{|c|}{ Funding } & \multicolumn{2}{|c|}{$\begin{array}{l}\text { Expensive } \\
\text { Equipment }\end{array}$} & \multicolumn{2}{|c|}{$\begin{array}{c}\text { Govt. } \\
\text { Regulation }\end{array}$} & \multicolumn{2}{|c|}{ Welfare } & \multicolumn{2}{|c|}{ Harassment } & \multicolumn{2}{|c|}{$\begin{array}{c}\text { Debt from } \\
\text { Advert }\end{array}$} & $\begin{array}{c}\text { Unfavourable work } \\
\text { Condition }\end{array}$ & \\
\hline & Freq & $\%$ & Freq & $\%$ & Freq & $\%$ & Freq & $\%$ & Freq & $\%$ & Freq & $\%$ & Freq & $\%$ & \\
\hline AlT & 10 & $7 \%$ & 11 & $7.7 \%$ & 12 & $8.4 \%$ & 9 & $6.3 \%$ & 12 & $8.4 \%$ & 10 & $7 \%$ & 11 & $7.7 \%$ & \\
\hline Rhythm & 9 & $6.3 \%$ & 10 & $7 \%$ & 11 & 7.7 & 9 & $6.3 \%$ & 11 & $7.7 \%$ & 8 & $5.9 \%$ & 9 & $6.3 \%$ & \\
\hline Total & 19 & 13.3 & 21 & 14.7 & 23 & $16 \%$ & 18 & 12.6 & 23 & $16 \%$ & 18 & 12.6 & 20 & $14 \%$ & $99.2 \% 142$ \\
\hline
\end{tabular}

Source: Field survey, 2018

142 respondents attested to the fact that there are challenges affecting private broadcast media, thus, the reason behind the use of 142 . The prevalent areas noted include the funding, expensive equipment, government regulation and legislation, welfare, government harassment, debt accruing from the advertising agents, and the unfavourable working condition amounted of media personnel.

\subsection{Research Question 2: Are there challenges peculiar to AIT and Rhythm 93.7fm as private} broadcast stations?

Table 2: Challenges peculiar to AIT and Rhythm $93.7 \mathrm{fm}$

\begin{tabular}{|l|c|c|c|c|c|}
\hline Station & Freq (Yes) & $\%$ & Frequency (No) & $\%$ & \\
\hline AIT & 78 & $47 \%$ & 7 & $4.2 \%$ & \\
\hline RHYTHM & 70 & $43 \%$ & 8 & $4.9 \%$ & \\
\hline TOTAL & 148 & $90 \%$ & 15 & $9.1 \%$ & 163 \\
\hline
\end{tabular}

Source: Field survey, 2018

One hundred and forty eight (148) out of the 163 respondents said that there are problems peculiar to their stations. However, question 9 which says, if yes state the challenges. The following responses were given: irregular payment of salaries, government incessant check on the station, government refusal for change over to digital transmission, overcrowding of the company by relatives of media owners, thereby causing disaffection, favouritism and mediocrity, debt by advert agencies, incessant shut down as a result of thunder thereby affecting transmission and irregular and epileptic power supply, thereby running generator 24 hours daily.

\subsection{Research Question 3: What are the prospects of private broadcast media in Nigeria?}

Table 3: Prospects of private broadcast media

\begin{tabular}{|c|c|c|c|c|c|c|c|c|c|c|c|c|c|c|c|}
\hline \multirow[t]{2}{*}{ Station } & \multicolumn{2}{|c|}{$\begin{array}{c}\text { More job } \\
\text { opportunities }\end{array}$} & \multicolumn{2}{|c|}{$\begin{array}{l}\text { Improved } \\
\text { economy }\end{array}$} & \multicolumn{2}{|c|}{$\begin{array}{l}\text { Younger } \\
\text { people will } \\
\text { show } \\
\text { interest }\end{array}$} & \multicolumn{2}{|c|}{\begin{tabular}{|l} 
Laws of \\
profession \\
would be \\
respected
\end{tabular}} & \multicolumn{2}{|c|}{$\begin{array}{c}\text { More } \\
\text { investors }\end{array}$} & \multicolumn{2}{|c|}{$\begin{array}{c}\text { More } \\
\text { professionals } \\
\text { would be } \\
\text { raised }\end{array}$} & \multicolumn{2}{|c|}{$\begin{array}{c}\text { Stand a } \\
\text { chance of } \\
\text { competing with } \\
\text { the rest of the } \\
\text { world }\end{array}$} & \\
\hline & Freq & $\%$ & Freq & $\%$ & Freq & $\%$ & Freq & $\%$ & Freq & $\%$ & Freq & $\%$ & Freq & $\%$ & \\
\hline AlT & 12 & $8.4 \%$ & 10 & $7.0 \%$ & 9 & $6.3 \%$ & 12 & $8.4 \%$ & 7 & $4.9 \%$ & 11 & $7.8 \%$ & 10 & $7.0 \%$ & \\
\hline Rhythm & 11 & $7.8 \%$ & 9 & $6.3 \%$ & 10 & $7.0 \%$ & 10 & $7.0 \%$ & 12 & $8.4 \%$ & 11 & $7.8 \%$ & 7 & $4.9 \%$ & \\
\hline Total & 23 & $16.2 \%$ & 19 & $13.3 \%$ & 19 & 13.3 & 22 & 15.4 & 19 & $13.3 \%$ & 22 & $15.6 \%$ & 17 & $11.9 \%$ & $99 \% 141$ \\
\hline
\end{tabular}

Source: Field survey, 2018 
The respondents were of the view that if an enabling environment is created, the private broadcast sector will enjoy the points contained in the boxes, thereby forming the prospects of the private broadcast media outfit.

\section{Conclusion and Recommendations}

The fulcrum of this study is on examining in totality, the challenges and prospects of private electronic media in the Nigerian landscape. To properly handle this task, the study narrowed down to Africa Independent Television (AIT) and Silverbird's Rhythm 93.7fm both in Port Harcourt.

It should, however be noted that through the revelation from this study that all is not well with the private broadcast media outfits, as lots of challenges hamper their performance, such that their successes have been hanging in a balance, thereby reducing the chances of achieving their set goals.

More than anything else, success would be the order-of-the- day and, the world information and communication order would be achieved via the existence of private broadcast stations, thereby achieving not only the millennium development goal, but the global target of the world as a village throughout the world and Nigeria in particular. Thus, the following recommendations are proffered, the implementation of which is hoped will mitigate the challenges affecting the broadcast media and help maximize their prospects for ultimate development:

1. Management and other operatives should comply with laws guiding the profession and nation.

2. The operators must be given free hand to operate, but not without respect for professionalism.

3. Tariff for importation of broadcast equipment should be reduced to enhance productivity and participation.

4. Training of staff should be top on priority to enhance productivity.

5. Those placing adverts should be made to pay before broadcast of their advertisement, to avoid piling debts, thereby affecting the welfare of staff, as well as running of the station.

6. Salaries of workers should be paid regularly and on time; to avoid strike, which will affect transmission.

7. Positions of authority in the private broadcast stations should be a product of a sheer dint of hard work, merit and capabilities and not through sentiment and favoritism; to avoid mediocrity and low productivity.

8. Government should avoid incessant harassment of practitioners and operators, as well as media owners, by so doing; a level playing field would be created.

\section{References}

Abubakar, Y. (1993). The role of the Nigeria mass media in the national rural development and transformation efforts with particular reference to electronic media. In E. O. Akeredolu-Ale (Ed.), Mass Media and Rural Development in Nigeria. Ibadan: Spectrum Books Limited.

Akpan, C.S. (2002). Sound and Sight Communication (1 ${ }^{\text {st }}$ ed.). Nsukka: Prize Publishers.

Asemah, E.S., Nwaammuo \& Nkwam-Uwaoma. (2017). Theories and Models of Communication. Jos: Jos University Press.

Ezeokoli, V.C. (1993). Using the Radio for Rural Development. In E.O. Akeredolu-Ale (Ed.), Mass Media and Rural Development in Nigeria. Ibadan: Spectrum Books Limited.

Mcquail, D. (1987). Mass Communication Theory: An introduction (2 ${ }^{\text {nd }}$ ed.). New Delhi: Sage Publication Inc.

Nwanze, I. (2003). Broadcasting in Nigeria (1 ${ }^{\text {st }}$ ed.). Port Harcourt: Renaissance Communication Limited.

Odetoyinbo, A. (2001). Basic Broadcast Production Techniques ( $1^{\text {st }}$ ed.). Abeokuta: Nicolack Visual Communication and Advertising Company.

Okoro, N. and Agbo, B. (2003). Writing for Media Society (1st ed.). Nsukka: Prize Publishers.

Udoakah, N. (1998). Development Communication (1 ${ }^{\text {st }}$ ed.). Lagos: String — Horden Publishers (Nig) LTD.

Umechukwu, P.O. (2001) Mass Media and Nigeria Society (1 ${ }^{\text {st }}$ ed.). Enugu: Thompson Prints and Publishing Company.

Yalaju, J. G. (2001). Media Law (1 ${ }^{\text {st }}$ ed.). Port Harcourt: Mission Publishers. 